\title{
In-vitro Evaluation of Botanicals, Fungi-toxic Chemicals and Bio-control Agent for Efficacy against Turcicum Leaf Blight of Maize
}

\author{
Subash Subedi ${ }^{1 @}$, Saraswati Neupane ${ }^{1}$, Surendra $\mathrm{BK}^{2}$ and Lokendra $\mathrm{Oli}^{1}$ \\ ${ }^{1}$ Nepal Agricultural Research Council,National Maize Research Program, Rampur, Chitwan, Nepal; \\ @: subedi.subash1@gmail.com, ORCID: https://orcid.org/0000-0003-3739-1773; SN: \\ sarusanu2017@gmail.com; LO: lokendraolinarc@gmail.com \\ ${ }^{2}$ Nepal Polytechnic Institute, Purbanchal University, Bharatpur, Chitwan, Nepal; SBK: \\ bksurendra18@gmail.com \\ Received 14 Jan 2019, Revised 15 Feb 2019, Accepted 25 Feb 2019, \\ Published 28 April 2019 \\ Scientific Editors: Bedanand Chaudhary, Jiban Shrestha, Santosh Subedi \\ Copyright (C) 2019 NARC. Permits unrestricted use, distribution and reproduction \\ in any medium provided the original work is properly cited. \\ The authors declare that there is no conflict of interest.

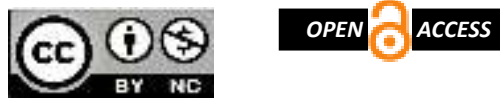 \\ Licensed under the Creative Commons Attribution \\ NonCommercial 4.0 International (CC BY-NC 4.0)
}

\begin{abstract}
Maize is the second most important cereal crop of Nepal. Its growth and production is severely affected by Turcicum leaf blight caused by Exserohilum turcicum at pre-harvest stage. A total of 6 botanicals, 4 chemical fungicides and 1 bio-control agent were evaluated for efficacy against Exserohilum turcicum under in vitro conditions following poisoned food technique at National Maize Research Program, Rampur, Nepal. The experiment was carried out in a completely randomized design with 5 replications. All the tested botanicals, fungicides and bio-control agent exhibited fungicidal action and significantly inhibited mycelial growth of the test pathogen over untreated control. Among botanicals, extract of Acorus calamus L. at 1\% W/V checked the pathogen growth completely in-vitro. The mycelial growth inhibition percent of Artimisia indica Willd, Lantana camera L., Allium sativum L., Xanthoxylum armatum DC., and Azadirachta indica A. Juss. at the concentration of $2.5 \% \mathrm{~W} / \mathrm{V}$ on PDA was $75.18 \%, 74.00 \%, 44.68 \%, 44.21 \%$ and $37.59 \%$ respectively. Among fungicides, the mycelial growth inhibition percent of E. turcicum due to ACME-COP (Copper oxychloride 50\% WP), SAAF (Carbendazim 12\% + Mancozeb 63\% WP), Dithane M-45 (Mancozeb 75\% WP) and Bavistin (Carbendazim 50\% WP) at the concentration of $1000 \mathrm{ppm}$ on PDA was $70.69 \%, 68.44 \%, 61.23 \%$, and $60.52 \%$ respectively. Antagonist Trichoderma viride developed more rapidly than E. turcium in single as well as in dual cultures. $T$. viride caused significantly inhibition of $35 \%$ of the pathogen E. turcicum on the $5^{\text {th }}$ day of incubation. These results have important implications for the management of turcicum leaf blight disease in maize.
\end{abstract}

Keywords: Biological control, Exserohilum turcicum, fungicides, mycelial inhibition, plant extracts.

\section{सारांश}

मकै वालीमा लाग्ने उत्तरी पात डढ़वा रोगको कारक ढ़सी इक्जेरोहीलम टरसीकम विरुद्ध स्थानिय तहमा नै उपलब्ध छ प्रकारका वानस्पतिक जडिबुटीहरु, $\checkmark$ प्रकारका रसायनिक विषादी र 9 प्रकारको जैविक ढुसिको प्रयोग गरि राष्ट्रिय मकैवाली अनुसन्धान कार्यकम रामपुर, चितवनको केन्द्रिय प्रयोगशालामा सजिव वस्तु वाहिर (इनभिट्रो)अर्न्तगत विशाक्त खाध प्रविधि परिक्षण मार्फत गरिएको थियो। उक्त परिक्षणहरु पुर्ण रेन्डमाइज्ड ढाँचा (सि.आर.डि) मा पाँचपटक दोहोज्याइ व्यवस्थित गरिएको थियो। वानस्पतिक जडिबुटी तर्फवाट वोकोको पानी मिश्रित सार तत्वको न्यूनतम मात्रा ( $\%$ डव्लु./भी.) ले रोग कारक ढुसिको वृद्धि पूर्ण रुपमा रोकी ढुसिलाइ मारेको पाइयो साथै तीतेपाती, वनफाडाकांडा, लसुन, टीमुर र नीमको छुट्टा-छुछै पानी मिश्रित सार तत्वको मात्रा (२. \%\% डव्लु. /भी.) ले रोग कारक ढुसिको माइसेलियम वृद्धि निसेध प्रतिशत क्रमशः ७४.१५\%, ७४\%, ४૪.६५\%, ४૪.२१\% र ३७.४९\% गरेको पाइयो। रसायनिक विषादी (मात्रा १००० पी.पी.एम) को तर्फवाट एक्मीकप (कपर अक्सीक्लोराइड पू\%डव्लु.पी.) ले ढुसिको माइसेलियम वृद्धि निसेध प्रतिशत ७०.६९\% गरेको पाइयो भने साफ (कारवेन्डाजीम १२\% +म्यान्कोजेव ६३\%डव्लु.पी) को हकमा ६६. ४४\%, डाइथेन एम ४४ (म्यान्कोजेव ७५\%डव्लु.पी) को हकमा ६१.२३\% र वेभिष्टिन (कारवेन्डाजीम प०\% डव्लु.पी) को हकमा ६०. ४२\% पाइयो। जैविक ढुसि र रोगकारक ढुसि एकैसाथ वृद्धिगर्ने प्रविधि (ड्यूलकल्चर टेक्निक) को नतिजा अनुसार उष्मायन अवधिको पांचौ दिनमा नै जैविक ढुसि ट्राइकोडर्मा भिरिडी पर्स. ले रोग कारक ढुसि इक्जेरोहीलम टरसीकमको माइसेलियमलाइ पूर्ण रुपमा छोपी ढुसिको वृद्धि रोक्न सफल भएको पाइयो जसमा ढुसिको माइसेलियम वृद्धि निसेध प्रतिशत ३५ \% रहेको थियो । 


\section{INTRODUCTION}

There are various biotic and abiotic stresses which are responsible for the feeble yield of maize (Zea mays L.) in Nepal; however, different diseases and poor crop management practices are most important among them (Subedi 2015). Maize is invaded by several fungal pathogens, but ubiquitous incidence of turcicum leaf blight caused by Exserohilum turcicum at pre-harvest stage is the most important bottleneck in satisfactory maize production (NMRP 2015).Heavy dews, cool temperature and frequent rains are environmental conditions conducive for disease development (Jordan et al 1983). The pathogen first identified in Nepal in 1964 from Patan, Lalitpur (Khadka and Shah 1967, Manandhar 1980). The disease is widely distributed throughout the country; however, it is more prevalent in the cool and humid conditions of the foothills and also common in the winter maize of the terai region. It was not considered as the major disease of maize crop in Nepal until 1985(Dahal et al 1992).The disease usually appears before tasseling cause yield loss upto40 to70\% and has become the most important disease at present in Nepal (NMRP 2016). Late sown maize in the summer season is most affected by this disease in hills (Manandhar et al 2007). The objective of this work was to evaluate the plant extracts, chemical fungicides and bio-control agents for their efficacy against Exserohilum turcicum causing northern leaf blight of maize under in vitro condition.

\section{MATERIALS AND METHODS}

\section{Experimental site and isolation of pathogen}

The samples of northern leaf blight disease specimens were collected from maize (Zea mays $\mathrm{L} .2 \mathrm{n}=$ $2 \mathrm{x}=20$ ) growing maize fields of National Maize Research Program (NMRP), Rampur and brought in to the Plant pathology laboratory during winter season of 2017. The infected leaves were cut in to several small sections 5-10 mm-square from the margin of the infected lesion to contain both diseased and healthy tissue. Then they were placed in surface sterilizing agents' solutions $(1 \% \mathrm{NaOCl})$ for about 15-30 seconds and the sections were taken out aseptically and blotted dry on clean, sterile paper towels or washed in three changes of sterile water and placed on the nutrient medium, usually three to five sections per dish. The pathogen, E. turcicum, grew from the sections and the colonies of the pathogen were sub cultured aseptically for further study.

\section{Botanicals and preparation of extracts}

The botanicals selected for the experiments were Sweet flag (AcoruscalamusL. $2 \mathrm{n}=4 \mathrm{x}=48$ ), Prickly ash (Xanthoxylum armatum DC. $2 \mathrm{n}=2 \mathrm{x}=66$ ), Mugwort (Artimisia indicaWilld. $2 \mathrm{n}=2 \mathrm{x}=18$ ), Neem (Azadirachta indica A. Juss. $2 \mathrm{n}=2 \mathrm{x}=28$ ), Lantana (Lantana camera $\mathrm{L} .2 \mathrm{n}=2 \mathrm{x}=22$, 44) and Garlic (Allium sativum $\mathrm{L} .2 \mathrm{n}=2 \mathrm{x}=16$ ). The dried fruits of prickly ash, stolos of sweet flag, garlic and fresh leaves of neem, mugwort and Lantana camera, were used to prepare the extract. These materials were dried in the shade for two days. While preparing the extracts, the unwanted debris was removed, surface sterilized for 2 minutes in $70 \%$ ethanol, and washed in three changes of sterile distilled water. The paste was obtained by grinding 1,2 and $2.5 \mathrm{~g}$ each of prickly ash, sweet flag, neem, garlic, mugwort and lantana plants separately in $100 \mathrm{ml}$ of sterile distilled water using a mortar and pestle. The paste was squeezed and filtered through 4 folds of sterile cotton wool into a $150 \mathrm{ml}$ conical flask to give concentrations of 1,2 and 2.5\% W/V (Wokocha and Okereke 2005). The volume of the filtrate collected was $100 \mathrm{ml}$ and each of the extract concentration was kept aseptically in $150 \mathrm{ml}$ conical flasks. The content in the flasks was exposed to UV light for further sterilization.

\section{Fungicides and bio-control agents}

The chemical fungicides used for the experiment were Dithane M-45 (Mancozeb 75\% WP), SAAF (Carbendazim 12\% + Mancozeb 63\% WP), ACME-COP (Copper oxychloride 50\% WP) and Bavistin (Carbendazim 50\% WP). The concentration level maintained was $1000 \mathrm{ppm}$. The bio-control agent used for the experiment was laboratory isolated culture of Trichoderma viride.

\section{In-vitro test}

The in-vitro test of plant extracts and fungicides against Exserohilum turcicum was done at the laboratory of NMRP, Rampur, Chitwan during 2017 winter. The experiment was carried out by poisoned food technique with completely randomized design (CRD). The linear growth was measured after 15 days of incubation. Different concentrations of water extracts of plants and fungicides (1000 
ppm) were individually incorporated into different conical flasks containing $100 \mathrm{ml}$ of sterile molten potato dextrose agar medium prepared from the dehydrated PDA (HIMEDIA, REF MO96-500G) as per the instructions of the manufacturer in the laboratory condition. The plant extracts and fungicides were added to the PDA separately when it was cooled to about $50^{\circ} \mathrm{C}$ with the help of micro-pipette. The flasks were gently agitated for 2 min to allow for a proper mixing of extract with the nutritive medium then $20 \mathrm{ml}$ medium was poured in the petri-plates $(9 \mathrm{~cm}$ diameter). Strepto-penicillin (Bistrepen-V) (250 mg per litre) was added to the medium at the time of pouring to prevent bacterial contamination. In case of plant extracts, there were a total of seven different treatments consisting of prickly ash, sweet flag, mugwort, neem, lantana, garlic and control. The concentration of botanicals was maintained to 1,2 and $2.5 \% \mathrm{~W} / \mathrm{V}$. There were 6 experimental setting consisting of prickly ash, sweet flag, mug-wort, neem, lantana and garlic extract. Each experiment included 4 treatments; plant extract at $1 \% \mathrm{~W} / \mathrm{V}, 2 \% \mathrm{~W} / \mathrm{V}$ and $2.5 \% \mathrm{~W} / \mathrm{V}$ including control (without any extract). In case of fungicides, there were 5 treatments consisting of Dithane M-45 (Mancozeb 75\% WP), SAAF (Carbendazim 12\% + Mancozeb 63\% WP), ACME-COP (Copper oxychloride 50\% WP), Bavistin (Carbendazim 50\% WP) and control. The concentration level maintained for the fungicides was 1000 ppm. Four mm diameter of E. turcicum of one week old culture was cut by cork borer and picked up with the help of inoculating needle and placed onto the center of the plate. The plate contained PDA amended plant extract and fungicides where the cut piece was kept upside down for better contact of pathogen to the media. The plates were incubated in incubator at $25^{\circ} \mathrm{C}$ for up to 15 days.

\section{Observation}

The colony diameter $(\mathrm{mm})$ of the pathogen was determined by measuring the average radial growth on different incubation dates. Average radial growth was recorded by using a measuring scale from the lower view of the petri-plates.

Mycelial growth inhibition percent was calculated by following formula.

Mycelial growth inhibition $(\%)=[(\mathrm{dc}-\mathrm{dt}) / \mathrm{dc}] \times 100$

Where $\mathrm{dc}=$ average diameter of fungal colony in the control and $\mathrm{dt}=$ average diameter of fungal colony in the treatment group

The antagonist effect of bio-control agent was evaluated against E. turcicum in dual culture technique. Four mm diameter of tested pathogen of one week old culture and above stated bio control agent was cut by cork borer and picked up with the help of inoculating needle and placed apart on solidified PDA medium in an equal distance comprising 5 replications and incubated as stated earlier. Observations were recorded by measuring colony diameter of both the test fungus and bio agent on different days of incubation up to 5 days and per cent inhibition was calculated.

\section{Statistical analysis}

The recorded observations were analyzed statistically using MSTAT-C computer package program and treatment means were compared using Duncan's Multiple Range Test (DMRT) at $1 \%$ levels of significance

\section{RESULTS}

All tested botanicals inhibited radial mycelial growth of Exserohilum turcicum significantly over the control at different concentrations (Table 1). The sweet flag (Acorus calamus L.) even at lower dose $(1 \% \mathrm{~W} / \mathrm{V}$ on PDA) was able to check completely the growth of pathogen $(4.00 \mathrm{~mm})$. With the increase in concentration $(2.5 \% \mathrm{~W} / \mathrm{V})$, the mean colony diameter of the E. turcicum in the plate amended with mugwort (Artimisia indica) and lantana (Lantana camera L.) was significantly lower i.e. $21.0 \mathrm{~mm}$ and $22.0 \mathrm{~mm}$ respectively than the diameter recorded at control plate. However, the mean colony diameter of the pathogen did not differ significantly at $2.5 \% \mathrm{~W} / \mathrm{V}$ dose when the plates were amended with prickly ash (Xanthoxylum armatum DC.) and garlic (Allium sativum) separately up to $15^{\text {th }}$ day of incubation period (Figure 1). The mycelial growth inhibition percent of Artimisia indica Willd, Lantana camera L., Allium sativum L., Xanthoxylum armatum DC., and Azadirachta indica A. Juss. at the concentration of $2.5 \% \mathrm{~W} / \mathrm{V}$ on PDA was $75.18 \%, 74.00 \%, 44.68 \%, 44.21 \%$ and $37.59 \%$ respectively (Table 2 ). 
Table1. Effect of plant extracts incorporated PDA on the growth of $E$. turcicum in different concentration levels at $25^{\circ} \mathrm{C}$ temperature during 2017 at NMRP, Rampur, Chitwan, Nepal

\begin{tabular}{lccc}
\hline Treatment & \multicolumn{3}{c}{ Mean colony diameter $(\mathbf{m m})$} \\
\cline { 2 - 4 } & $\mathbf{1 \%} \mathbf{W / V}$ & $\mathbf{2 \%} \mathbf{~ W / V}$ & $\mathbf{2 . 5 \%} \mathbf{W} / \mathbf{V}$ \\
\hline Acorus calamus & $\dagger .00^{\mathrm{g}}$ & $4.00^{\mathrm{f}}$ & $4.00^{\mathrm{e}}$ \\
\hline Xanthoxylum armatum & $73.00^{\mathrm{c}}$ & $57.00^{\mathrm{c}}$ & $47.20^{\mathrm{c}}$ \\
\hline Artimisia indica & $43.60^{\mathrm{e}}$ & $23.80^{\mathrm{e}}$ & $21.00^{\mathrm{d}}$ \\
\hline Azadirachta indica & $56.00^{\mathrm{d}}$ & $55.40^{\mathrm{c}}$ & $52.80^{\mathrm{b}}$ \\
\hline Lantana camera & $57.60^{\mathrm{d}}$ & $26.80^{\mathrm{d}}$ & $22.00^{\mathrm{d}}$ \\
\hline Allium sativum & $79.00^{\mathrm{b}}$ & $72.80^{\mathrm{b}}$ & $46.80^{\mathrm{c}}$ \\
\hline PDA only & $84.60^{\mathrm{a}}$ & $84.60^{\mathrm{a}}$ & $84.60^{\mathrm{a}}$ \\
\hline F test & $* *$ & $* *$ & $* *$ \\
\hline LSD (0.01) & 2.42 & $2.66^{\mathrm{a}}$ & 3.13 \\
\hline CV\% & 2.43 & 3.28 & 4.50
\end{tabular}

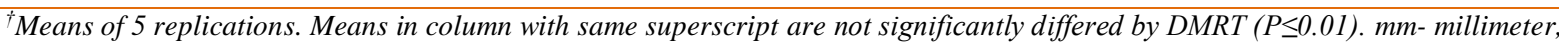
W/V- Weight by volume, PDA- Potato Dextrose Agar, **- highly significant

Table2. Effect of plant extracts incorporated PDA on mycelial growth inhibition of $E$. turcicum in different concentration levels at $25^{\circ} \mathrm{C}$ temperature during 2017 at NMRP, Rampur, Chitwan, Nepal

\begin{tabular}{lccc}
\hline Treatment & \multicolumn{3}{c}{ MGI \% } \\
\cline { 2 - 4 } & $\mathbf{1 \%} \mathbf{W / V}$ & $\mathbf{2 \%} \mathbf{W} / \mathbf{V}$ & $\mathbf{2 . 5 \%} \mathbf{W} / \mathbf{V}$ \\
\hline Acorus calamus & 95.27 & 95.27 & 95.27 \\
\hline Xanthoxylum armatum & 13.71 & 32.62 & 44.21 \\
\hline Artimisia indica & 48.46 & 71.87 & 75.18 \\
\hline Azadirachta indica & 33.81 & 34.52 & 37.59 \\
\hline Lantana camera & 31.91 & 68.32 & 74.00 \\
\hline Allium sativum & 6.62 & 13.95 & 44.68 \\
\hline
\end{tabular}

PDA only

MGI- Mycelial Growth Inhibition, W/V- Weight by volume, PDA- Potato Dextrose Agar

All the tested fungicides incorporated PDA had significant $(\mathrm{p}<0.01)$ effect on the growth of the Exserohilum turcicum at $25^{\circ} \mathrm{C}$ as compared to control at $1000 \mathrm{ppm}$ concentrations up to $15^{\text {th }}$ dayof incubation (Table 3). There was no significant difference between Bavistin (Carbendazim 50\% WP) and Dithane M-45 (Mancozeb 75\% WP) to reduce the growth of Exserohilum turcicum in all the dates of incubation. The fungicides SAAF (Carbendazim 12\% + Mancozeb 63\% WP) and ACME-COP (Copper oxychloride 50\% WP) had also the same effect to check the growth of pathogen (Figure 2). The mean colony diameter of the pathogen in the plate amended with ACME-COP(Copper oxychloride 50\% WP), SAAF (Carbendazim 12\% + Mancozeb 63\% WP), Dithane M-45 (Mancozeb 75\% WP) and Bavistin (Carbendazim 50\% WP) was significantly lower ie $24.80 \mathrm{~mm}, 26.70 \mathrm{~mm}$, $32.80 \mathrm{~mm}$ and $33.40 \mathrm{~mm}$ respectively than the control plate $(84.60 \mathrm{~mm})$ on $15^{\text {th }}$ day of incubation. The mycelial growth inhibition percent of E. turcicum due to ACME-COP (Copper oxychloride $50 \% \mathrm{WP}$ ), SAAF(Carbendazim 12\% + Mancozeb 63\% WP), Dithane M-45 (Mancozeb 75\% WP)and Bavistin (Carbendazim 50\% WP) at the concentration of 1000 ppm on PDA was 70.69\%, 68.44\%, 61.23\%, and $60.52 \%$ respectively.

Table 3. Effect of fungicides incorporated PDA on the growth of $E$. turcicum in concentration level (1000 ppm) at $25^{\circ} \mathrm{C}$ during 2017 at NMRP, Rampur, Chitwan, Nepal

\begin{tabular}{lcc} 
Treatments (Concentration: 1000 ppm) & Mean colony diameter (mm) & MGI\% \\
\hline Dithane M-45 (Mancozeb 75\% WP) & $\dagger 32.80^{\mathrm{b}}$ & 61.23 \\
\hline SAAF(Carbendazim 12\% + Mancozeb 63\% WP) & $26.70^{\mathrm{c}}$ & 68.44 \\
\hline ACME-COP (Copper oxychloride 50\% WP) & $24.80^{\mathrm{c}}$ & 60.69 \\
\hline Bavistin (Carbendazim 50\% WP) & $33.40^{\mathrm{b}}$ & \\
\hline Control (only PDA) & $84.60^{\mathrm{a}}$ & \\
\hline F test & $* *$ & 3.15 \\
\hline LSD $(0.01)$ & 4.33
\end{tabular}

Means of 5 replications. Means in column with same superscript are not significantly different by LSD (P<0.01) mm-millimeter, MGIMycelial Growth Inhibition, ppm- parts per million, WP-wettable powder, PDA = Potato Dextrose Agar, **- highly significant 


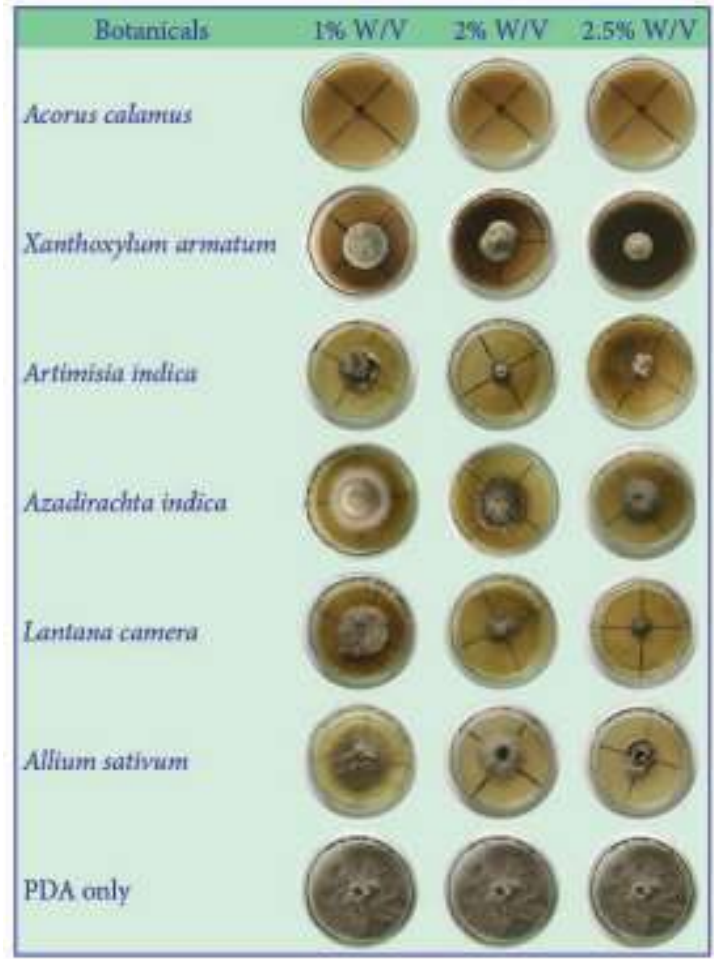

Figure1. Effect of plant extracts on the growth of $E$. turcicum in different concentration levels at $25^{\circ} \mathrm{C}$ during 2017 at NMRP, Rampur, Chitwan

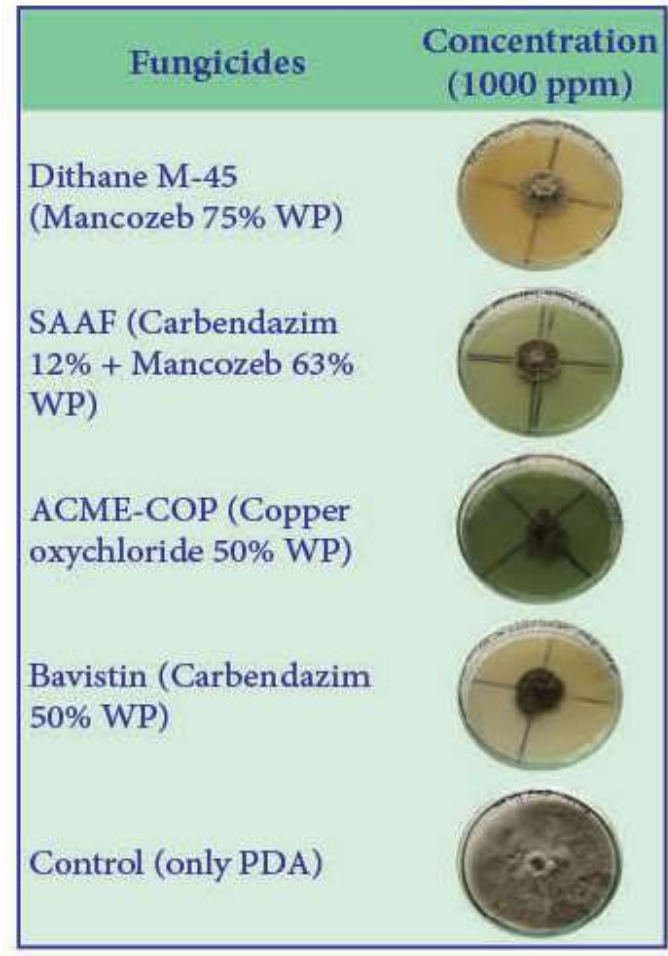

Figure 2. Effect of fungicides on the growth of $E$. turcicum in different concentration levels at $25^{\circ} \mathrm{C}$ during 2017 at NMRP, Rampur, Chitwan

The mean colony diameter of the antagonist was significantly higher than the pathogen, E. turcicum, on $5^{\text {th }}$ day of incubation at $25^{\circ} \mathrm{C}$ (Table 4). Less $(18.60 \mathrm{~mm})$ mean colony diameter of the pathogen was measured when dual culture was done with Trichoderma viride Pers. (PPD isolate). The diameter of the pathogen alone was $28.60 \mathrm{~mm}$ on $5^{\text {th }}$ day of incubation at room temperature. The mean colony diameter of the antagonist $T$. viride was noticed higher in dual culture with E. turcicum in all days of incubation compared to the diameter of $T$. viride grown alone in PDA (Figure 3). It was observed that the growth of the antagonist was enhanced in dual culture with pathogen than the antagonist alone grown in PDA while the growth of the pathogen was less in dual culture with antagonist compared to the pathogen grown alone in PDA in all days of incubation.

Table 4. Effect of Trichoderma viride on the growth of $E$. turcicum in different incubation periods at $25^{\circ} \mathrm{C}$ during 2017 at NMRP, Rampur, Chitwan

\begin{tabular}{lccccc}
\hline Treatment & \multicolumn{5}{c}{ Mean colony diameter $(\mathbf{m m})$} \\
\cline { 2 - 6 } & 1st day & 2nd day & 3rdday & 4th day & 5th day \\
\hline Trichoderma viride only & $120.80^{\mathrm{b}}$ & $50.20^{\mathrm{b}}$ & $68.00^{\mathrm{b}}$ & $83.20^{\mathrm{a}}$ & $88.80^{\mathrm{a}}$ \\
\hline T. viride in dual culture with E. turcicum & $28.80^{\mathrm{a}}$ & $61.80^{\mathrm{a}}$ & $73.90^{\mathrm{a}}$ & $85.10^{\mathrm{a}}$ & $88.30^{\mathrm{a}}$ \\
\hline Excerohilum turcicum only & $11.00^{\mathrm{c}}$ & $14.40^{\mathrm{c}}$ & $21.80^{\mathrm{c}}$ & $24.40^{\mathrm{b}}$ & $28.60^{\mathrm{b}}$ \\
\hline E. turcicum in dual culture with T. viride & $7.40^{\mathrm{d}}$ & $13.60^{\mathrm{c}}$ & $15.40^{\mathrm{d}}$ & $17.80^{\mathrm{c}}$ & $18.60^{\mathrm{c}}$ \\
\hline F test & $* *$ & $* *$ & $* *$ & $* *$ & $* *$ \\
\hline LSD $(0.01)$ & 2.00 & 2.63 & 3.67 & 2.92 & 2.69 \\
\hline CV\% & 6.38 & 4.07 & 4.44 & 3.00 & 2.60 \\
\hline
\end{tabular}

${ }^{\dagger}$ Means of 5 replications. Means in column with same superscript arenot significantly different by LSD (P<0.01). mmmillimeter, **- highly significant 


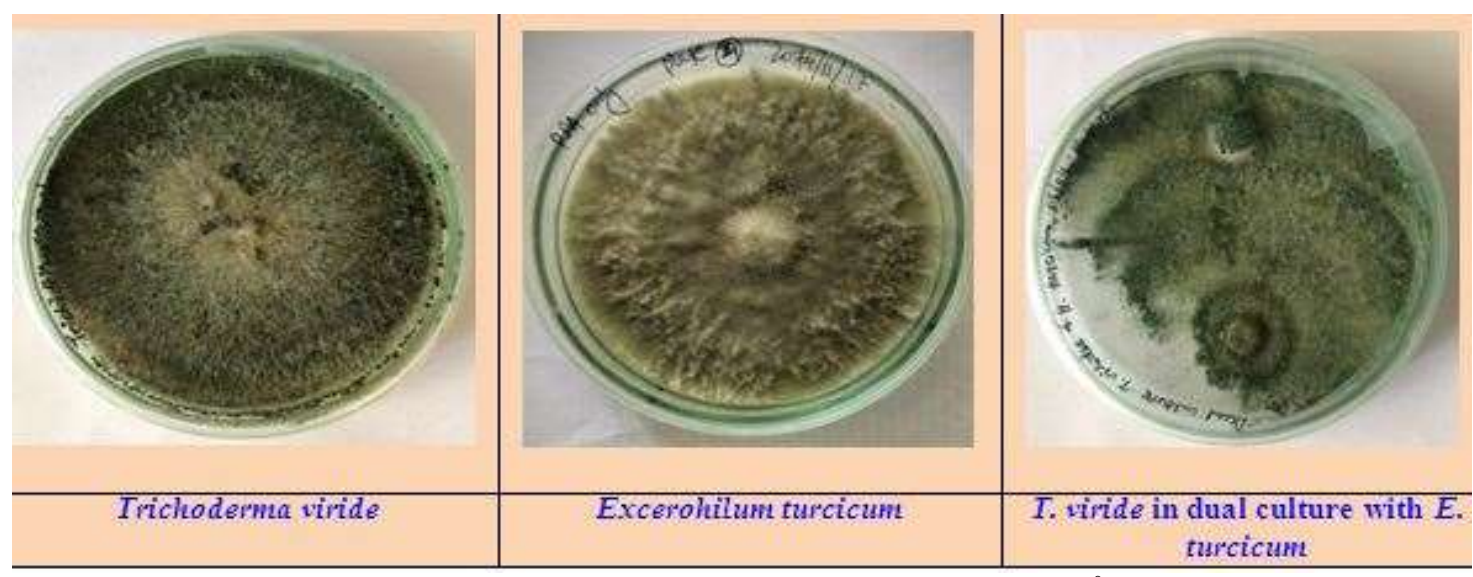

Figure 3. Effect of Trichoderma viride on the growth of E. turcicum at $25^{\circ} \mathrm{C}$ during 2017 at NMRP, Rampur, Chitwan.

\section{DISCUSSION}

As the plant pathogens develop resistance to many fungicides it creates immense problem to control various crop diseases which pushes to search for new and alternative fungi-toxic substance from various sources including plant extracts. The results indicated that the various phyto-extracts tested inhibited the mycelia growth of E. turcicum as compared to control. However, there was no further growth of the pathogen on the PDA incorporated with Acorus calamus extract at 1\% W/V in all the dates of incubation. Even at the lower dose $0.5 \% \mathrm{~W} / \mathrm{V}$ on PDA, Acorus calamus extract significantly check the growth of the pathogen followed by Artimisia indica and Lantana camera at higher concentration level $(2.5 \% \mathrm{~W} / \mathrm{V})$. Similar results on antifungal activity of aqueous extracts of different plants has been reported by various workers (Shivapuri et al 1997, Meena et al 2003). From the present study, it is concluded that Acorus calamus L., Artimisia indica and Lantana camera L. were effective botanicals to suppress the growth of E. turcicum. A perusal of literature showed similar experiments regarding the control of E. turcicum using plant extracts has not yet been done in Nepal and very few literatures were available. Phongpaichit et al(2005) investigated that an antimicrobial guided one of methanol extracts of A. calamus containing $\beta$-asarone as a major component showing high antifungal activity against Microsporum gypseum Bodin, Trichophyton rubrum Castell. and Penicillium marneffei Segretain and had moderate activity against Candida albicans Berkhout and Cryptococcus neoformans Vuill. The findings of Kungha (1999) also indicated that alcoholic extract of A. calamus could inhibit many fungi including Alternaria brassicae Sacc, Fusarium oxysporum f.sp. lycopersici, Rhizoctonia solani Kuhn, Sclerotiana sclerotiorum de Bary at the concentration of $0.10 \%$ upward. The major antifungal compound found in A. calamus is $\beta$-asarone which is considered to be the most biological active compound in the rhizome of $A$. calamus and quantities of $\beta$-asarone vary $10-20 \%$ in the rhizome of European origin while in Asia, it was found in the range of $70-90 \%$ (Karwowska et al 1997). Findings of current study are in agreement with the report of Deena and Thoppil (2000) who described the essential oil of Lantana camera containing B-caryophyllene, geranyl acetate, terpinyl acetate, bornyl acetate and limonene remarkably inhibited the growth of many tested bacteria and fungi. Aspergillus niger Tieghem, Fusarium solani Schlecht and Candida albicans Berkhout appeared as the most sensitive ones. Khedkar et al (2012) studied the efficacy of phyto extract on E. turcicum by poisoned food technique under in vitro conditions and found that Nimbicidin@5\% concentration was superior to all other treatments with the maximum mycelial inhibition of $68.85 \%$ followed by negunda (38.88\%) and neem seed kernel extract (37.01\%). Subedi et al (2015) also reported that Acorus calamus L. was the most effective botanical followed by Xanthoxylum armatum when tested against Stemphylium botryosum Walr. both at in vitro and in vivo condition.

The finding of this experiment is also in agreement with the Wani et al (2017) who found that among fungicides, Mancozeb was found best (95.23\% mean inhibition) and among plant extracts, neem oil inhibited maximum mycelial growth of E. turcicum (62.33\%). Investigations also indicated that 
mancozeb was most effective in controlling Turcicum leaf blight of maize (Pandurangegowda 1987, Begum et al 1993). Reddy et al (2013) evaluated seven fungicides in vitro against $E$. turcicum causing leaf blight of maize and found treatment mancozeb @ $0.25 \%$ and combination treatment of mancozeb and carbendazim, i.e, Saff @ 0.25\% recorded the lowest per cent disease index (PDI) reducing the disease by 73.0 and $72.1 \%$, respectively.

Antagonist Trichoderma viride Pers. showed the potentials to suppress the radial colony growth of $E$. turcicum under laboratory condition. T. viride developed more rapidly than E. turcium in single as well as in dual cultures. The intensive development of Trichoderma gives it a significant advantage in competition with pathogens for nutrients and space, besides the production of mycotoxins. In vitro evaluation of bio-control agents revealed that Trichoderma viride caused significantly inhibition (35\%) of the pathogen E. turcicum on $5^{\text {th }}$ day of incubation. The inhibitory effect of these bio-agents was probably due to competition and / or antibiosis. The antagonism of $T$. viride observed in the present studies is in tune with the findings of various workers (Biles and Hill 1988, Mahamood et al 1995, Ramachandra 2000). The mechanism of Trichoderma to control pathogens may be by attacking and binding the pathogenic organisms by sugar linkage and begins to secrete extracellular protease and lipase (Cal et al 2004). Trichoderma sp. grown over the pathogenic fungal hyphae, coils around them and degrades the cell walls. This action of parasitism restricts the development and activity of pathogenic fungi. Additionally, or together with mycoparasitism, some Trichoderma species release antibiotics (Harman 2006). According to Rosado et al (2007), the main factor for ecological success of this genus is a combination of very active mycoparasitism mechanisms and an effective defensive strategy, induced in the plants.

All the tested botanicals, fungicides and bio-control agent exhibit fungicidal action and inhibit mycelial growth of the Exserohilum turcicum. Among botanicals, extract of Acorus calamus L. at lower dose also completely check the pathogen growth in-vitro. At higher dose, plant extracts of Artimisia indica Willd, Lantana camera L., Xanthoxylum armatum DC., Allium sativum L. and Azadirachta indica A. Juss. are also effective to reduce the mycelial growth of E. turcicum. Among fungicides, ACME-COP (Copper oxychloride 50\% WP), SAAF (Carbendazim 12\% + Mancozeb 63\% WP), Dithane M-45 (Mancozeb 75\% WP)andBavistin(Carbendazim 50\% WP) at the concentration of $1000 \mathrm{ppm}$ on PDA are effective to check the growth of the pathogen. Antagonist Trichoderma viride Pers. suppresses the radial colony growth of E. turcicum and develops more rapidly than E. turcium in single as well as in dual cultures.

\section{ACKNOWLEDGEMENTS}

Authors would like to express gratitude to the NMRP Coordinator and NARC for financial support in this study. The research team of NMRP, Rampur is gratefully acknowledged for trial management and data recording. All people who provided valuable opinions and ideas are also appreciated.

\section{REFERENCES}

Begum H, RB Raj and E Satyanarayana.1993.Field evaluation of five fungicides to control Turcicum leaf blight in maize. Indian Journal of Plant Protection.21:110-116.

Biles CL and JPHILL. 1988. Effect of Trichoderma harzianum on sporulation of Cochliobolus sativus on excised wheat seedling leaves. Phytopathology.78:656-659.

Cal A, I Larena, P Sabuquillo and P Melgarejo. 2004. Biological control of tomato wilts. Recent Research Development and Crop Science. 1:97-115.

Dahal G, P Amatya and HK Manadhar. 1992. Plant diseases in Nepal-country profile. Review of Plant Pathology.71(11):797-807.

Deena MJ and JE Thoppil. 2000. Antimicrobial activity of the essential oil of L. camara. Fitoter.71:453-457.

Harman GE. 2006. Overview of mechanisms and uses of Trichoderma spp. Phytopathology.96:190-194.

Jordan EG, JM Perkins, RA Schall and WL Pederson. 1983. Occurrence of race 2 of Exserohilum turcicum on corn in central United States. Plant Disease.67:1163-1165.

Karwowska K, J Stegman, W Duszkiewiez-reinhard and A Dobrzeniecka. 1997. Studies on isolation and chemical composition of biologically active compounds of calamus (Acorus calamus). Horticulture 18:109-113. 
Khadka BB and SM Shah. 1967. Preliminary list of plant diseases recorded in Nepal. Nepalese Journal of Agriculture.2:47-76.

Khedekar SA, SI Harlapur, S Kulkarni and VI Benagi. 2012. Evaluation of fungicides, botanicals and bioagents against Turcicum leaf blight of maize caused by Exserohilum turcicum(Pass.) Leonard and Suggs.International Journal of Plant Protection 5(1):58-62.

Kungha T. 1999. Effect of clove, sweet flag, star anise and Chinese cassia extracts on some plant pathogenic molds.Master Thesis.Chiang Mai University, Chiang Mai.80p.

Mahamood A, N Javed, R Ahmad and ZI Raheel. 1995. Biological control of maize leaf blight caused by Helminthosporium turcicum Pass in vitro. Pakistan Journal of Phytopathology 7:62-64.

Manandhar G, S Baidya, DC Paudel and RR Burlakoti.2007.Evaluation of maize genotypes for resistant to northern leaf blight disease in Nepal. In: Proceedings of the $25^{\text {th }}$ National Summer Crops Research Workshop on Maize Research and Production in Nepal (DB Gurung, DC Paudel, G KC, SR Upadhyay and BB Pokhrel, eds).June 21-23, 2007,Nepal Agriculture Research Institute, NARC, Khumaltar, Lalitpur, Nepal.pp.273-275.

Manandhar KL. 1980. Review on maize diseases investigation from 1975-1980. In: Proceedings of the 8th Summer Crops Workshop, 25-30 January 1980, National Maize Development Program, Rampur, Chitwan, Nepal. pp.255-278.

Meena RL, RS Rathore and K Mathur. 2003. Evaluation of fungicides and plant extracts against banded leaf and sheath blight of maize. Indian Journal of Plant Protection.31:94-97.

NMRP. 2015. Annual Report 2071/72 (2014/15) (S Subedi, TB Karki, J Shrestha and G Bhandari, eds). National Maize Research Program, NARC, Rampur, Chitwan, Nepal.198p.

NMRP.2016.AnnualReport2072/73(2015/16) (S Neupnae, R Sharma, S Sharma and J Shrestha, eds). National Maize Research Program, NARC, Rampur, Chitwan, Nepal.157p.

PandurangegowdaKT.1987.Status of breeding and management of Turcicum leaf blight of maize. In: Progressive Report of 30th Annual Maize Workshop, 17-20 April, 1987, AICMIP, IARI, New Delhi, India. pp.21-28.

Phongpaichit S, N Pujenjob, V Rukachaisirikul and M Ongsakul. 2005. Antimicrobial activities of the crude methanol extract of Acorus calamus Linn. Journal of Science and Technology.27(2):517- 523.

Ramachandra CG. 2000. Studies on leaf blight of Dicoccum wheat caused by Exserohilum hawaiiensis (Bugnicourt). Master Thesis. Subram. and Jain, Ex. Ellis, M.B. University of Agricultural Sciences, Dharwad.120p.

Reddy TR, NP Reddy, RR Reddy and SS Reddy. 2013. Management of Turcicum leaf blight of maize caused by Exserohilum turcicum in maize. International Journal of Scientific and Research publications 3(10):1-4.

Rosado I, M Rey, A Codon, J Gonavites, MA Moreno-mateos and T Benitez. 2007. QID74 Cell wall protein of Trichoderma harzianum is involved in cell protection and adherence to hydrophobic surfaces. Fungal Genetics and Biology 44(10):950-964.

Shivapuri A. OP Sharma and SL Jhamaria.1997.Fungitoxic properties of plant extracts against pathogenic fungi. Journal of Mycology and Plant Pathology.27:29-31.

Subedi S.2015.A review on important maize diseases and their management in Nepal. Journal of Maize Research and Development 1(1):28-52. DOI: https://doi.org/10.3126/jmrd.v1i1.14242

Subedi S, SM Shrestha, GB KC, RB Thapa, SK Ghimire, DB Gharti and S Neupane. 2015. Evaluation of plant extracts against Stemphylium blight of lentil. Nepal Journal of Science and Technology.16 (1):11-16.

Wani TA, A Mushta and A Anwar. 2017. Evaluation of Fungicides, Bioagents and Plant Extracts against Exserohilum turcicum causing Turcicum Leaf Blight of Maize. International Journal of Current Microbiological Applied Science 6(8):2754-2762.

Wokocha RC and VC Okereke.2005.Fungitoxic activity of extracts of some medicinal plants on Sclerotium rolfsii causal organism of the basal stem rot diseases of tomato. Nigerian Journal of Plant Protection.22:106-110.

$|1--1| 1---1 \mid$. 